\title{
AGAMA DAN POLITIK DALAM TRADISI PERAYAAN REBO WEKASAN
}

\author{
Abdul Chalik \\ UIN Sunan Ampel Surabaya \\ Jl. Jend. A. Yani No. 117, Jemur Wonosari, Surabaya, Jawa Timur, 60237 \\ E-mail: achalik@yahoo.co.id
}

Abstract: Rebo Wekasan which is celebrated on the last Wednesday in Safar month is one of religious ritual by doing prayer, bathing, reading sholawat and other ritual activities. This ritual is intended to thank to Allah and to reject calamities. This is held since the attendance of Tumenggung Jamaludin Malik to spread Islam as ordered by Sunan Giri. The Rebo Wekasan festivity is composed form the social construct toward the externalisation, objectivity, and internalisation process. Sheikh Jamaludin Malik came to Suci spreading the religion in many obstacles. After succeeded in all those troubles then the communitiy celebrates in some rituals which becomes traditions from generations to generations, then they maintain it although it is beyond their consciousness. Nowadays Rebo Wekasan is shifted into political moment since the local government makes this celebration into a socialisation, agitation, and political activities. This is possible to happen because there are so many visitors who usually come to Gresik and join the celebration.

Keywords: Rebo Wekasan, local religious, traditions, and politics.

Abstrak: Perayaan Rebo Wekasan menjadi ritual keagamaan dalam bentuk salat, mandi, membaca salawat dan kegiatan keruhanian yang lain. Ritual ini dilakukan pada hari Rabu terakhir bulan Safar. Perayaan Rebo Wekasan bertujuan untuk mensyukuri nikmat Allah serta untuk menolak berbagai musibah. Ritual tersebut dilaksanakan sejak kedatangan Tumenggung Jamaludin Malik untuk menyiarkan agama Islam atas perintah Sunan Giri. Perayaan Rebo Wekasan terbentuk dari proses konstruksi sosial melalui proses eksternalisasi, objektifikasi dan internalisasi. Syekh Jamāl al-Dīn Malik datang ke Suci untuk menyebarkan agama Islam dengan berbagai kesulitan, setelah dapat meretas kesulitan kemudian masyarakat merayakannya dalam bentuk ritual, selanjutnya masyarakat menganggap bahwa ritual tersebut merupakan tradisi yang harus dipertahankan meskipun mereka bertindak di luar kesadarannya. Momen Rebo Wekasan yang 
asalnya ritual keagamaan mulai bergeser ke momen politik. Kepentingan banyak pihak, terutama pihak desa dan pemerintah daerah menjadikan momen Rebo Wekasan sebagai ajang sosialisasi, agitasi, dan kegiatan politik yang sama sekali tidak memiliki hubungan dengan ritual keagamaan. Hal tersebut dapat terjadi karena banyaknya pengunjung dan jamaah yang ikut merayakan kegiatan tersebut dari berbagai penjuru Gresik maupun luar Gresik.

Kata Kunci: Rebo Wekasan, keberagamaan lokal, tradisi, dan politik.

\section{A. Pendahuluan}

Islam datang di Nusantara ketika agama-agama besar seperti Hindu dan Buddha mengurat nadi dan menjadi way of life selama berabad-abad lamanya. Di tempat yang berbeda, ajaran animisme dengan segala bentuk keyakinan dan ritualnya juga mengalami masa perkembangan di mana agama dan keyakinan itu menyatu dalam kehidupan masyarakat. Ketika saudagar dan ulama Timur Tengah datang menyebarkan Islam, tradisi-tradisi yang mengakar kuat di masyarakat dibiarkan berlangsung apa adanya dan sebagian pula disesuaikan dengan syariat Islam. Proses pembiaran dan perubahan tradisi nenek moyang secara bertahap ke syariat Islam ini cukup ampuh untuk mempengaruhi keimanan masyarakat, dan secara perlahan pula Islam diterima sebagai agama baru yang mampu beradaptasi dengan budaya dan tradisi yang sudah lama dianut oleh masyarakat.

Sebagai akibat dari pembiaran tradisi menyatu dalam syariat Islam, maka muncul berbagai praktik keagamaan yang beragam namun tidak mengurangi substansi ajaran Islam sebagaimana yang diajarkan oleh al-Qur'an. Tafsir keagamaan oleh berbagai suku dan etnis kemudian melahirkan apa yang disebut oleh beberapa ilmuwan seperti Geertz (Geertz,1981: 53), Woodward (Woodward, 2006: 132), Mulder (Mulder, 1999: 56), sebagai Islam lokal, yakni Islam yang identik dengan identitas lokal di mana Islam itu menjadi keyakinan penduduk di masing-masing daerah, terutama di Jawa. Munculnya kluster Islam Jawa, Islam Melayu, Islam Banjar dan Islam Bugis yang merupakan ekspresi dari keberagamaan Islam nusantara.

Praktik Islam lokal pada satu sisi mengantarkan Islam nusantara yang dinamis dan beragam, tetapi pada sisi lain juga mengantarkan pada sulitnya membedakan antara syariat dan tradisi. Sering kali ditemukan terjadi pembauran antar keduanya, dan tidak jarang pula ditemukan tradisi menjadi syariat dan syariat menjadi tradisi. Hal ini yang terjadi pada perayaan Rebo Wekasan. 
Kegiatan perayaan Rebo Wekasan dalam tradisi masyarakat Suci Manyar Gresik merupakan bagian dari ekspresi keagamaan yang sudah lama berlangsung di tengah masyarakat. Perayaan Rebo Wekasan seolah menjadi keniscayaan bagi masyarakat Gresik terutama Desa Suci di mana perayaan tersebut dilakukan tiap tahun secara besar-besaran.

Kegiatan Rebo Wekasan secara besar-besaran dirayakan oleh masyarakat Desa Suci kecamatan Manyar kabupaten Gresik. Di tempat lain di Jawa Timur atau di luar Jawa Timur sebagian merayakan hal yang sama, meskipun dilakukan secara terbatas dalam skala individu. Namun di Desa Suci, perayaan tersebut dilakukan secara besar-besaran, yang berlangsung rutin setiap tahun. Pada dasarnya perayaan Rebo Wekasan tidak ditemukan pendasaran yang cukup kuat dalam ajaran Islam, terutama yang berkaitan dengan salat pada malam Rebo Wekasan. Dalam Islam berbagai salat baik wajib maupun sunah telah disebutkan dalam hadis Nabi SAW secara lengkap yang termuat dalam berbagai kitab hadis. Salat wajib atau salat sunah merupakan ibadah yang telah ditentukan Allah dan Rasul-Nya, baik tata cara mengerjakannya maupun waktunya. Dalam perkembangannya, Rebo Wekasan menjadi momentum penting dalam perjalanan Islam di Kabupaten Gresik. Motif dan pendorong untuk memperkuat tradisi tersebut terus menggema, dan semakin lama semakin kuat dan membesar. Selain persoalan keyakinan keagamaan, ruang ekonomi dan politik ikut memberikan andil dalam memperbesar ruang Rebo Wekasan untuk terus eksis.

Artikel ini akan mengkaji masalah Rebo Wekasan dalam perspektif masyarakat serta hubungan tradisi dengan persoalan politik. Untuk membantu analisis, penulis akan menggunakan Teori Konstruksi Sosial (Sobur, 2002: 21), (Weber, 1978: 312). Pada bagian ini akan dikaji bagaimana masyarakat mengkonstruksi kehidupan individu ke dalam kehidupan masyarakat melalui pemaduan antara ajaran keagamaan dengan tradisi. Terjadi dialektika antara individu menciptakan masyarakat dan masyarakat menciptakan individu. Proses dialektika ini terjadi melalui eksternalisasi, objektivasi, dan internalisasi.

\section{B. Akar Sejarah Rebo Wekasan dan Proses Pembentukannya}

Sejarah Rebo Wekasan memiliki latar belakang akar sejarah dengan berdirinya Desa Suci. Rebo Wekasan mulai ada bersamaan dengan berdirinya Desa Suci. Sejarah Desa Suci ${ }^{1}$ dimulai semenjak zaman Sunan Giri. Konon

${ }^{1}$ Desa Suci merupakan salah satu desa yang berada di Kecamatan Manyar. Dari pusat Kecamatan Manyar, Desa Suci terletak sekitar $4 \mathrm{~km}^{2}$ dengan batas-batas wilayah sebelah utara berbatasan dengan desa Pongangan dan Sukomulyo, sebelah Timur berbatasan dengan desa 
Sunan Giri (Mustopo, 2001: 55) (Tim Penyusun Sejarah Hari Jadi Kota, 1991: 60 : pernah Singgah di desa Polaman -sekarang Desa Suci (Tim Desa, 2013: 10). Namun tidak betah yang menurut $\mathrm{Fahmi}^{2}$ dikarenakan kondisi dan situasi masyarakat Polaman yang suka berbuat tercela seperti minum-minuman dan lain sebagainya, sehingga kemudian Sunan Giri pada akhirnya memilih untuk bertapa di Pegunungan Giri.

Kemudian Sunan Giri mengutus santri yang sekaligus masih familinya yang bernama Syekh Jamāl al-Dīn Malik $k^{3}$ untuk menyebarkan agama Islam di desa Polaman. Setelah Syekh Jamāl al-Dīn Malīk berada di desa Polaman, ia mendirikan sebuah masjid sekaligus menjadi pesantren yang memiliki fungsi untuk tempat beribadah sekaligus belajar ilmu agama Islam. Masjid tersebut kemudian diberi nama Masjid Roudhotus Salam. Masjid saat ini berdiri kokoh dan menjadi simbol desa.

Karena semua masyarakat Polaman mengetahui bahwa Syekh Jamāl al-Dīn Malik merupakan santri sekaligus famili Sunan Giri, maka masyarakat tersebut kemudian berguru dan belajar ilmu agama Islam sekaligus belajar ibadah kepada beliau sehingga saat itu Syekh Jamāl al-Dīn Malik memiliki santri yang cukup banyak. Karena banyaknya santri itulah, maka Syekh Jamāl al-Dīn Malik membuat sebuah sumur yang kemudian dikenal dengan nama Sumur Gede (Miftach, 2008: 2).

Semakin tahun semakin banyak santri yang belajar ilmu agama kepada Syekh Jamāl al-Dīn Malik. Karena semakin banyaknya santri maka kebutuhan air pun semakin banyak apalagi pada musim kemarau air dari Sumur Gede sering mengalami kekeringan karena tidak ada air lebih-lebih pada musim kemarau. Oleh karenanya Syekh Jamāl al-Dīn Malīk meminta saran kepada Sunan Giri. Kemudian Sunan Giri menyarankan kepada Syekh Jamāl al-Dīn Malīk untuk menelusuri lereng bukit di sebelah utara Desa Polaman untuk

Yosowilangun, sebelah selatan berbatasan dengan desa Dahan Rejo dan Kembangan dan di sebelah Barat berbatasan dengan desa Tebalo dan Banjarsari. Luas wilayah Desa Suci sekitar 3,89 $\mathrm{km}^{2}$ atau 389.522 ha. Dengan luas wilayah 3,89 $\mathrm{km}^{2}$, maka wilayah desa suci di kelompokkan menjadi beberapa wilayah berdasarkan pada aspek penggunaan tanah. Pada aspek itu tanah Desa Suci berupa tanah sawah seluas 51,60 ha, berupa tanah kering seluas 118,11 ha, berupa tanah pekarangan seluas 191,93 ha dan jenis tanah-tanah yang lain luasnya sekitar 27,38 ha (Tim Desa, 2013:5).

${ }^{2}$ Wawancara dengan Fahmi. Fahmi adalah tokoh setempat yang memahami alur sejarah Rebo Wekasan.

${ }^{3}$ Nama lain Syeikh Jamaluddin Malik adalah Tumenggung Sono. Wawancara Syahid (Syahid adalah tetua dan tokoh lokal Desa Suci). 
mencari sumber air. Setelah itu Syekh Jamāl al-Dīn Malik melihat rerimbunan pohon-pohon besar di tempat lereng tersebut yang terdiri dari pohon randu, pohon beringin, pohon abar, pohon kayu tangan, dan pohon kesono yang membentuk sebuah gerumbulan. Kemudian di bawah pohon-pohon tersebut Syekh Jamāl al-Dīn Ma Tik menemukan sumber air yang sangat jernih dan sangat besar hingga airnya meluap ke permukaan tanah dan sangat sesuai dengan kebutuhan bersuci menurut syariat agama Islam. Karena itulah kemudian sumber air tersebut dikenal dengan nama Blumbang atau Pemandian Sendang Sono, (Miftach, 2008: 2) sedangkan wilayah sekitar Sendang Sono disebut dengan Desa Suci.

Kemudian Syekh Jamāl al-Dīn Malīk memindahkan masjid yang ada di desa Polaman ke Desa Suci yang berada di sebelah sumber air Sendang Sono. Karena situasi dan perkembangan zaman masjid tersebut berpindah-pindah, dari Polaman ke dekat sumber air Sendang Sono kemudian pada masa penjajahan Jepang dipindah ke Kampung Gombang sebelah barat desa, dan setelah masa Indonesia merdeka masjid tersebut dipindah lagi. Namun atas saran para tokoh masyarakat kemudian masjid tersebut ditempatkan di tengah-tengah desa. Sampai sekarang masjid itu tetap berdiri megah dengan nama Masjid Roudlotus Salam, Sedangkan di tanah bekas masjid yang dipindah tersebut juga didirikan masjid yang lokasinya tepat di depan sumber air Sendang Sono yang kemudian diberi nama masjid Mamba'ut Tho'at (Miftach, 2008: 4).

Setelah ditemukan sumber air, Sunan Giri memerintahkan kepada Syekh Jamāl al-Dīn Malik untuk mengajak masyarakat pada hari Selasa malam Rabu terakhir pada bulan Safar untuk mandi dan berwudu di sumber air tersebut. Selanjutnya dilakukan salat sunah ${ }^{4}$ yang diakhiri dengan sujud syukur sebagai bentuk rasa syukur dan terima kasih kepada Tuhan yang telah memberikan kenikmatan berupa sumber air yang sangat melimpah dan jernih dan sekaligus memohon agar diberikan keselamatan dan dijauhkan dari segala penyakit. Kemudian masyarakat kembali pulang dengan membawa air dari Sendang Sono untuk diminum oleh keluarga di rumah agar memperoleh barokah yang kemudian kegiatan ini-membawa pulang air dari Sendang Sono-menurut masyarakat Desa Suci disebut dengan tabarrukan (mengharap barokah).

${ }^{4}$ Pada umunya masyarakat menyebutnya salat Rebo Wekasan. Ada perbedaan pendapat mengenai jenis salat apa yang dilakukan, menurut tokoh ulama 'Arifin (wawancara) dan Syahid, salat tersebut adalah salat Mutlaq; menurut Miftach adalah salat Hajat (wawancara). Tetapi dari berbagai informasi yang penulis peroleh kebanyakan adalah salat Mutlaq. 
Sejak dimulainya ritual tersebut, Syeikh Jamaluddin Malik bersama masyarakat Suci pada tahun berikutnya menyelenggarakan kegiatan yang sama pada hari Rabu terakhir dalam bulan safar dengan ritual yang sama dan akhirnya kegiatan tersebut dilaksanakan secara terus-menerus dan berulang-ulang setiap tahun sehingga menjadi kebiasaan masyarakat Suci yang selanjutnya disebut dengan tradisi Rebo Wekasan oleh masyarakat desa Suci (Miftach, 2008: 10).

Perayaan Tradisi Rebo Wekasan dilaksanakan di masjid Mamba'ut Tho'at, yaitu masjid yang berada di sebelah utara Desa Suci yang berada di depan sumber air Sendang Sono Wedoaan. Di masjid tersebutlah kegiatan dan ritual-ritual Rebo Wekasan dilaksanakan.

Di masjid tersebut tradisi Rebo Wekasan dilaksanakan selama 2 (dua) hari, yaitu hari Senin malam Selasa hingga Selasa malam Rabu. Pada hari Senin malam Selasa kegiatannya adalah Khotmil Qur'an yang dimulai sejak pagi hingga sore. Kemudian dilanjutkan dengan pembagian air Rebo Wekasan ${ }^{5}$ kepada masyarakat dan pengunjung. Kemudian dilanjutkan dengan acara Asuban. Asuban adalah sebuah kegiatan hiburan yang berupa kesenian teater yang mengandung nilai-nilai Islam. Setelah itu dilanjutkan dengan kegiatan Kirab Tumpeng yang pelaksanaan-nya dilaksanakan dengan cara arak-arakan keliling mulai Masjid Nurud Dholam Kampung Asemanis ke Masjid Mamba'ut Tho'at. Di Masjid Mamba'ut Tho'at itulah kemudian pengunjung makan bersama tumpeng tersebut. Setelah itu dilanjutkan dengan pengajian umum atau tausiyah yang disampaikan oleh para kyai, tokoh agama atau pemerintah desa dan kabupaten.

Kemudian pada hari Selasa malam Rabu pengunjung dan masyarakat mandi dan bersuci di pemandian atau sumber air Sendang Sono, kemudian dilanjutkan dengan kegiatan Istighosah ${ }^{6}$ berjamaah yang berisi yāsīn, tahlil dan Salawat mulai maghrib hingga selesai. Kemudian kegiatan Rebo Wekasan diakhiri dengan kegiatan salat sunah mutlaq secara berjamaah yang diakhiri dengan sujud syukur.

Dalam proses pelaksanaan Rebo Wekasan, di luar Masjid Mamba'ut Tho'at, yakni di sepanjang jalan Desa Suci panitia kegiatan yang dipanitiai oleh pemerintah Desa Suci mengadakan hiburan-hiburan untuk menarik perhatian

${ }^{5}$ Air Rebo Wekasan adalah air dalam sebuah gelas yang telah diberi doa tertentu oleh seorang kyai atau tokoh agama.

${ }^{6}$ Berdasarkan informasi yang penulis peroleh biasanya aliran istigasah yang digunakan adalah aliran istigosah Qadiriyyah al-Naqsabandiyyah yang biasanya dipimpin oleh K. H. Bukhori Hadi dari desa Bungah Gresik. Wawancara dengan Arifin (tokoh agama setempat). 
pengunjung dan sekaligus menghibur mereka. Bentuk hiburan tersebut dari tahun ke tahun selalu mengalami perubahan sesuai dengan situasi dan kondisi masyarakat. Pada zaman dulu hiburan yang dominan adalah wayang kulit, panggung sandiwara islami, pencak silat, layar tancap, komedi putar, dan juga hadrah yang kesemuanya tersebut kurang dapat dilestarikan. Saat ini hanya seni hadrah yang masih diadakan setiap tahun (Miftach, 2008: 13).

Selain hiburan, di sepanjang jalan Desa Suci juga dipenuhi oleh berbagai jenis pedagang dan jasa yang menjajakan dan menawarkan barang dan jasanya. Pada zaman dulu terdapat banyak pedagang menjual makanan kecil dan minuman sederhana seperti Serebeh atau serabi raksasa dan wingko dari Desa Ndoro Banjarsari Kecamatan Manyar, dawet dan rujak legi dari desa Rumo kecamatan Manyar, kupat ketek dari Desa Giri Kecamatan Kebomas, dan kacang dengan dipikul dari Desa Benjeng dan Balong Panggang. Itulah pedagang yang pertama kali berjualan di Desa Suci dalam kegiatan Rebo Wekasan. Berbeda dengan zaman dulu, zaman sekarang banyak yang berdagang dengan beberapa jenis yang bervariasi, tidak hanya makanan dan minuman saja tetapi juga pakaian, jasa hiburan seperti ombak banyu, dan semacamnya, pijat refleksi, mainan, dan lain sebagainya.

Dalam mensukseskan pelaksanaan perayaan Rebo Wekasan, keterlibatan beberapa figur lokal Desa Suci sangat dominan, terutama tokoh kiai. Figur-figur tersebut ialah: kyai, pesantren, tokoh agama dan pemerintah desa. Dalam pelaksanaan Rebo Wekasan, kiai terlibat dalam beberapa bentuk keterlibatan yang bermacam-macam: Pertama, Kiai terlibat untuk memimpin ritual-ritual keagamaan dalam perayaan Rebo Wekasan seperti istigasah, tahlil, yāsīn, doa, dan ritual keagamaan dan khususnya memberikan doa pada segelas air yang kemudian dibagikan kepada santri dan masyarakat suci sebagai tabarrukan. Kedua, kiai terlibat sebagai penceramah dalam perayaan tersebut, seperti pemberi atau pengisi tawșiyyah-tawșiyyah agama atau ceramah agama di mana dalam konteks Rebo Wekasan dilakukan secara bergiliran setiap tahun.

Ketiga, kiai juga terlibat sebagai penyelenggara dan pelaksana perayaan di mana kiai terlibat di dalamnya dengan posisi sebagai dewan penasehat. Keempat, selain itu kiai juga terlibat dalam Rebo Wekasan sebagai tamu undangan saat perayaan, sebab tidak semua kiai merupakan figur lokal, tetapi ada pula kiai yang merupakan figur outsider yang sesungguhnya tidak memiliki mata rantai kesejarahan dengan Rebo Wekasan.

Dalam menyelenggarakan dan melaksanakan perayaan Rebo Wekasan masyarakat menggunakan dasar-dasar tertentu di mana dasar-dasar tersebut 
merupakan pondasi yang dapat memberikan kekuatan terhadap perkembangan dinamika perayaan Rebo Wekasan agar selalu selaras dan sejalan dengan syariat Islam dan kebudayaan. Dalam hal ini penulis dapat mengkategorikan dasardasar penyelenggaraan perayaan Rebo Wekasan dalam dua dasar, yaitu dasar keagamaan dan dasar budaya.

Berdasarkan pada dasar keagamaan, penulis dapat menggolongkannya menjadi dua perspektif, yaitu perspektif al-Qur'an dan perpektif pendapat ulama'. Dalam perspektif al-Qur'an, perayaan Rebo Wekasan yang diselenggarakan di Desa Suci merujuk pada firman Allah SWT dalam QS. Ibrahim: 7 yang berbunyi:

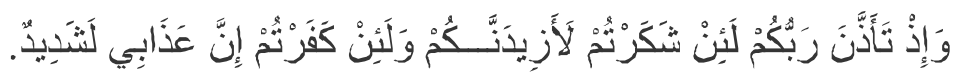

"Dan (ingatlah juga) tatkala Tuhanmu memaklumkan; "Bahwa Sesungguhnya jika kamu bersyukur, pasti Kami (Allah) akan menambah (nikmat) kepadamu, dan jika kamu mengingkari (nikmat-Ku), maka sesungguhnya azab-Ku sangat pedih"(QS. Ibrahim: 7).

Ayat di atas merupakan ayat yang memberikan interpretasi bahwa Allah telah memberitahukan janji-janjinya kepada manusia bahwa jika mereka dapat bersyukur at as nikmat yang diberikan oleh-Nya, maka niscaya ia akan menambah nikmat kepada manusia. Namun sebaliknya jika manusia mengingkari nikmatnya maka ia akan memberikan azab atau musibah kepada manusia dengan cara mengambil kembali nikmat itu dari mereka dan menyiksa mereka at as pengingkaran terhadap nikmat tersebut (Katsir, 1999: 263).

Firman Allah SWT di atas sesungguhnya sangat sesuai dengan latar belakang munculnya tradisi Rebo Wekasan, yaitu ditemukannya sumber air Sendang Sono yang jernih dan melimpah yang dapat digunakan untuk bersuci, serta pengairan sawah dan kebun. Sumber Sendang Sono tersebut merupakan kenikmatan yang dikaruniakan oleh Allah kepada masyarakat Suci. Oleh karena itu, kemudian Rebo Wekasan muncul sebagai media ungkapan rasa syukur dan terima kasih kepada Allah atas kenikmatan yang diberikan oleh Allah SWT kepada masyarakat Suci yang berupa sumber air Sendang Sono yang melimpah sehingga dapat digunakan untuk aktivitas kehidupan masyarakat.

Agar Allah tidak memberikan azab dan musibah dengan cara mengambil kembali kenikmatan yang telah diberikan dalam bentuk sumber air Sendang Sono tersebut, maka masyarakat berusaha untuk bersyukur dan menghindari rasa kufur terhadap nikmat Allah. Sebab jika masyarakat tidak mau bersyukur atas karunia dan nikmat yang dianugerahkan oleh Allah maka Allah akan 
mengambil nikmat yang diberikannya dan menggantikannya dengan musibah dan azab dan menyiksa masyarakat Suci terhadap pengingkaran tersebut.

Adapun dasar keagamaan dalam perspektif pendapat ulama tentang Rebo Wekasan antara lain; Pertama, menurut ulama terdahulu setiap bulan Safar Allah menurunkan beribu-ribu balā'. Karena itu para ulama' terdahulu membuat slametan (berdoa dan memberi sadoqah makanan) dan berdoa pada hari Rabu terakhir bulan Safar agar terbebas dari balā', musibah dan azab yang diturunkan oleh Allah. Kedua, Menurut kiai NU dasar tradisi Rebo Wekasan adalah sebuah kaidah fiqhiyah yang berbunyi Al- 'ādatu Muhakkamāt yang artinya sebuah tradisi, budaya atau kebiasaan dapat dijadikan sebagai dasar hukum (Bungin, 2006: 192).

Adapun dasar budaya penyelenggaraan tradisi Rebo Wekasan adalah melestarikan budaya Rebo Wekasan yang sesungguhnya merupakan tradisi masyarakat Desa Suci sejak dulu. Selain itu tradisi Rebo Wekasan saat ini merupakan identitas masyarakat Desa Suci yang harus selalu dilestarikan sehingga masyarakat tidak sampai kehilangan identitas mereka sendiri.

\section{Konstruksi Rebo Wekasan dalam Ruang Sosial}

Rebo Wekasan merupakan sebuah realitas objektif yang telah mengalami proses objektifikasi yang terlembagakan sejak lama oleh Sunan Giri bersama Syekh Jamāl al-Dīn Mālik melalui tindakan-tindakan sosial dan interaksi sosial dengan masyarakat sekitar Desa Suci. Hal ini artinya menunjukkan bahwa Rebo Wekasan tidak serta merta muncul. Tetapi ada proses-proses konstruksi yang dilakukan oleh Sunan Giri bersama Syekh Jamāl al-Dīn Mālik melalui rasionalisasi dan kepentingan-kepentingannya yang dilakukan secara terusmenerus dan berulang-ulang. Tradisi ini muncul melalui proses konstruksi sosial yang dilakukan oleh Sunan Giri dan Syekh Jamāl al-Dīn Mālik melalui momen eksternalisasi, objektifikasi dan internalisasi (Ritzer, G, 1992: 5).

Eksternalisasi. Dalam momen eksternalisasi, Sunan Giri bersama dengan Syekh Jamāl al-Dīn Mālik berusaha mengekspresikan kepentingan subjektifnya yang rasional ke dalam realitas sosial melalui tindakan dan interaksinya dengan masyarakat Suci. Dalam mengekspresikan kepentingannya, Sunan Giri dan Syekh Jamāl al-Dīn Mālik paling tidak melakukan 3 (tiga) tahapan momen eksternalisasi melaui tindakan dan interaksi yang dilakukan oleh Sunan Giri dan Syekh Jamāl al-Dīn Mālik kepada masyarakat Suci.

Pertama, Sunan Giri memerintahkan Syekh Jamāl al-Dīn Mālik untuk menyebarkan agama Islam di Desa Polaman dengan mendirikan masjid dan 
pesantren Roudhotus Salam serta membuat sebuah sumur yang kemudian disebut dengan Sumur Gede yang digunakan untuk bersuci dan pengairan. Hal ini merupakan momen awal konstruksi realitas sosial yang dilakukan oleh Sunan Giri melalui gagasan rasional subjektif dan kepentingannya untuk menyebarkan agama Islam di Desa Polaman melalui Syekh Jamāl al-Dīn Mālik.

Dengan semakin banyaknya masyarakat yang mendalami agama Islam maka semakin mudah bagi Sunan Giri untuk mengkonstruksi Tradisi Rebo Wekasan. Sebab alasan yang mendasar yang digunakan oleh Sunan Giri dalam meng-konstruksi Rebo Wekasan adalah penemuan sumber air Sendang Sono yang merupakan kebutuhan utama masyarakat Desa Suci. Selain ditemukannya sumber air Sendang Sono alasan mendasar lainnya adalah interaksi langsung oleh Sunan Giri untuk mengajak masyarakat untuk melaksanakan ritual Rebo Wekasan yang diyakini oleh Islam sebagai momen rasa syukur dan penolak musibah.

Kedua, Sunan Giri memerintahkan kepada Syekh Jamāl al-Dīn Mālik untuk pergi ke lereng bukit sebelah barat Polaman untuk mencari sumber air yang kemudian disebut dengan Sendang Sono. Dengan ditemukannya Sumber air yang bernama Sendang Sono inilah kemudian menjadi alasan yang paling kuat dan utama munculnya tradisi Rebo Wekasan. Ketiga, Sunan Giri mengajak langsung masyarakat untuk melakukan ritual Rebo Wekasan dengan rasionalisasi penemuan sumber air Sendang Sono dan rasa syukur terhadap penemuan sumber air tersebut sekaligus berdoa memohon untuk dijauhkan dari musibah dan mara bahaya pada hari Rabu akhir bulan Safar.

Dari ketiga deskripsi di atas menunjukkan bahwa sesungguhnya kepentingan dan kehendak dari Sunan Giri dan Syekh Jamāl al-Dīn Mālik terhadap Rebo Wekasan adalah penyebaran dan penguatan pemahaman keagamaan masyarakat Suci melalui ritual-ritual yang diajarkan Sunan Giri. Artinya secara substansi kepentingan Sunan Giri dan Syekh Jamāl al-Dīn Mālik adalah pada aspek keagamaan.

Dari deskripsi momen eksternalisasi di atas dapat dipahami bahwa usaha yang dilakukan mereka merupakan bentuk aktualisasi diri mereka dalam kehidupan masyarakat Suci. Pada momen eksternalisasi ini masyarakat Suci merupakan produk sosial dari Sunan Giri dan Syekh Jamāl al-Dīn Mālik. Artinya masyarakat Suci adalah produk konstruksi Sunan Giri dan Syekh Jamāl al-Dīn Mālik melalui tindakan mereka yang sesuai dengan rasionalitas dan kepentingan mereka.

Momen eksternalisasi ini terjadi ketika Sunan Giri dan Syekh Jamāl al-Dīn Mālik terlibat dalam tindakan dan interaksinya dengan masyarakat Desa Suci 
sehingga ketika tradisi Rebo Wekasan terbentuk oleh mereka. Dalam aspek ini, Rebo Wekasan merupakan bagian penting dari masyarakat Suci sehingga secara langsung maupun tidak langsung Rebo Wekasan menjadi bagian penting pula bagi Sunan Giri dan Syekh Jamāl al-Dīn Mālik sebagai pencipta Rebo Wekasan.

Pola semacam ini banyak terjadi dalam kehidupan muslim di Indoensia, terutama masyarakat Jawa. Proses semacam dapat dimaknai dalam dua hal, yang pertama perspektif keagamaan dan perspektif politik. Dalam perspektif keagamaan hal tersebut dapat dimaknai sebagai "sistesis mistik", sebuah istilah yang dikembangkan oleh Ricklefs (M.C. Ricklefs, 2013:36).

Sejak lama masyarakat Jawa mempercayai bahwa di luar kekuatan manusia terdapat kekuatan lain yang bersifat luar biasa. Kekuatan tersebut dapat bersumber dari Tuhan maupun kekuatan alam gaib yang melingkupinya. Kepercayaan terhadap Nyai Roro Kidul dan Sunan Lawu (roh Gunung Lawu), misalnya merupakan kekuatan adikodrati yang sangat melekat dengan masyarakat Jawa.

Ketika banyak para wali menyebarkan agama Islam di tanah Jawa, dan generasi penerus yang terlembagakan dalam kerajaan-kerajaan Islam Jawa, penggabungan Islam dan hal-hal yang bercorak mistik begitu kental. Hampir tidak persoalan keagamaan yang tidak luput dari sintesa mistik. Hal-hal yang bersifat rasional dan logis pun seringkali dipahami secara mistis.

Kedatangan Syekh Jamāl al-Dīn Mālik atas perintah Sunan Giri merupakan hal yang biasa. Sebagai seorang kepercayaan Sunan Giri, Syekh Malik menyampaikan ajaran-ajaran Islam secara wajar dengan menggunakan perspektif keagamaan. Namun setelah melakukan dakwah dan berhasil, maka masyarakat merayakannya dengan cara lain, yakni perayaan Rebo Wekasan dengan cara mandi di kolam, ruwat, salat sunah dan arak-arakan tumpeng menapaktilasi perjalanan Syekh Malik dalam menyebarkan agama Islam di bumi Suci.

Sementara dalam perspektif politik, apa yang dilakukan oleh Syekh Malik murni untuk kepentingan kekuasaan Kerajaan Giri, di mana Sunan Giri sebagai rajanya. Pada era itu, untuk memperluas dan memperkuat kekuasaan politiknya, Sunan Giri harus banyak melakukan pendekatan politik kepada masyarakat melalui cara-cara yang damai. Salah satunya adalah dengan mencari sumber air untuk keperluan irigasi, memasak dan ibadah. Sesuat u yang wajar dilakukan oleh seorang pemimpin.

Objektifikasi. Dalam proses objektifikasi Rebo Wekasan yang dilakukan oleh Sunan Giri dan Syekh Jamāl al-Dīn Mālik nampak bahwa Rebo Wekasan merupakan sebuah realitas empiris yang eksistensinya dapat dipahami dan 
dirasakan oleh semua masyarakat Suci. Pada fase momen objektifikasi Rebo Wekasan ini masyarakat Suci menjadi sebuah realitas, atau dapat pula dipandang sebagai proses interaksi sosial antara masyarakat Suci dengan Rebo Wekasan dalam realitas intersubjektif yang terlembagakan. Dalam momen objektifikasi Rebo Wekasan ini akan selalu terjadi dalam proses institusionalisasi yang berada dalam dunia intersubjektif. Dalam proses ini masyarakat Suci mengaktualisasikan dan mengekspresikan dirinya ke dalam tradisi Rebo Wekasan.

Momen objektifikasi Rebo Wekasan ini berkembang dan bertahan cukup lama sehingga sangat mudah bagi masyarakat Suci untuk memahaminya secara langsung oleh masyarakat Suci baik dengan kontak langsung dengan Sunan Giri dan Syekh Jamāl al-Dīn Mālik sebagaimana yang dilakukan oleh masyarakat suci zaman dulu maupun tanpa kontak dengan Sunan Giri dan Syekh Jamāl alDīn Mālik pada zaman sekarang ini. Karena masyarakat tidak harus melakukan kontak langsung dengan Sunan Giri dan Syekh Jamāl al-Dīn Mālik maka dalam memahami Rebo Wekasan masyarakat Suci cukup hanya melakukan pola intersubjektif dengan mengekspresikan diri individu-individu masyarakat Suci ke dalam Rebo Wekasan. Karena tidak ada kontak langsung dengan Sunan Giri dan Syekh Jamāl al-Dīn Mālik, maka Rebo Wekasan sesungguhnya dapat dilakukan melalui penyebaran opini dalam bentuk informasi lisan, baliho, pamflet, baner dan lain sebagainya kepada seluruh anggota masyarakat Suci sehingga semua masyarakat suci dapat memahami dan mengerti sehingga dapat mengekpresikan kepentingan-nya ke dalam Rebo Wekasan.

Dalam hal ini sesungguhnya yang terpenting dalam objektifikasi adalah reproduksi simbol-simbol. Oleh karenanya dalam momen objektifikasi Rebo Wekasan pada Zaman dulu Sunan Giri dan Syekh Jamāl al-Dỉn Mālik mereproduksi simbol-simbol agar mudah dipahami dan dimengerti oleh masyarakat Suci dengan beberapa bentuk di antaranya pemandian Sendang Sono, Masjid Roudhotus Salam, air minum Rebo Wekasan (Rabu akhir bulan Safar), salat Mutlaq dan sujud syukur, riyaḍoh, dan lain sebagainya. Pada zaman sekarang banyak sekali simbol-simbol Rebo Wekasan yang telah terobjektifikasi karena cukup lama melakukan proses reproduksi simbol antara lain pemandian Sendang Sono, air minum Rebo Wekasan (Rabu akhir bulan Safar) salat Mutlaq dan sujud syukur, serabi raksasa, lontong bumbu ladan, pedagang, hiburan, tumpeng, gambus, dan lain sebagainya.

Salah satu keberhasilan dakwah ketika mampu menciptakan simbol. Simbol merupakan instrumen untuk melekatkan suasana batin dengan isu dakwah. Simbol dan imej merupakan sesuatu yang tak terpisahkan. Syekh 
Jamāl al-Dīn Mālik dengan kemampuan dakwahnya mampu menciptakan simbol tersebut. Istilah Rebo Wekasan tidak ditemukan dalam referensi keagamaan Islam, terutama dari sumber referensi mu'tabarah yang menjadi rujukan utama para ulama dalam mengambil keputusan hukum. Referensi tersebut baru muncul setelah kedatangan Syekh Malik di Desa Suci dan melakukan dakwah dengan menggunakan cara-cara yang simpel dan mudah diterima oleh masyarakat.

Sedangkan dalam momen internalisasi, Rebo Wekasan dimasukkan kembali ke dalam kesadaran seorang anggota masyarakat Suci dalam segala bentuk dimana realitas subjektifnya dipengaruhi oleh Rebo Wekasan. Berbagai macam bentuk Rebo Wekasan tersebut kemudian ditangkap olehnya sebagai gejala yang berada di luar kesadarannya, sekaligus Rebo Wekasan tersebut menjadi gejala yang mengkonstruk internal kesadarannya. Melalui proses internalisasi inilah dia menjadi produk dari masyarakat.

Dalam momen internalisasi Rebo Wekasan seorang anggota masyarakat Suci menjadi anggota masyarakat dengan cara sosialisasi. Ia akan mengalami dua proses sosialisasi terhadap Rebo Wekasan yaitu sosialisasi primer dan sosialisasi sekunder.

Seorang anggota masyarakat suci melakukan proses sosialisasi primer tentang Rebo Wekasan pada saat dia kecil. Mereka dapat mengenal dan memahami Rebo Wekasan yang dikenalkan oleh orang tuanya, saudaranya, dan lainnya. Informasi tentang Rebo Wekasan yang terbatas dan berasal dari orang lain tersebut nyatanya sangat berpengaruh dan itu dianggap oleh si anak sebagai realitas yang nyata. Mengingat bahwa Rebo Wekasan tidak mungkin diserap dengan sempurna, maka si anak akan menginternalisasi penafsirannya terhadap Rebo Wekasan.

Setiap orang memiliki versi penafsiran terhadap Rebo Wekasan yang dianggapnya sebagai cermin dari kenyataan. Sosialisasi primer terhadap Rebo Wekasan dianggap berakhir ketika konsep tentang orang lain telah terbentuk dan tertanam dalam kesadaran individu. Pada batas ini, dia menjadi anggota dari masyarakat dan secara subjektif dia kemudian memiliki identitas diri sebagai anggota masyarakat.

Adapun dalam sosialisasi sekunder, seorang anggota masyarakat mengalami internalisasi sub realitas Rebo Wekasan Artinya dia telah mengalami proses pemerolehan pengetahuan khusus tentang Rebo Wekasan sesuai dengan perannya baik secara langsung maupun tidak langsung yang berasal dari sistem pembagian kerja dalam Rebo Wekasan Perannya dalam Rebo Wekasan yang 
diperoleh pada momen internalisasi melalui sosialisasi sekunder menjadi berbeda dengan peran individu Rebo Wekasan yang diperoleh saat internalisasi melalui sosialisasi primer. Hal ini terjadi sebab dalam proses internalisasi melalui sosialisasi sekunder individu melakukan proses identifikasi subjektif terhadap Rebo Wekasan yang terus berkembang sehingga dia mendapatkan peran yang baru dan berbeda dengan peran yang sebelumnya saat sosialisasi primer dalam Rebo Wekasan.

Dalam praktik keagamaan, terutama yang berafiliasi dengan pandangan Ahl al-Sunnah wa al-Jamā'ah, Rebo Wekasan dipraktikkan dalam kehidupan mereka. Hal tersebut banyak dilakukan oleh kalangan pesantren dan tarekat. Melalui pesantren dan tarekat terutama yang mu'tabarah al-nahdiyyah, ritual Rebo Wekasan dilaksanakan setiap tahun. Ada sebagian yang datang ke Desa Suci terutama masyarakat yang tinggal di Gresik dan sekitarnya, dan ada pula yang melakukan ritual di tempat masing-masing. Cara yang digunakan tidak dengan mandi sebagaimana yang terjadi di Desa Suci, melainkan dengan istighasah, tahlil, dan i'tikaf di Musala maupun di masjid.

Di Suci sebagai sentral Rebo Wekasan internalisasi ritual semakin menemukan momentum dengan hadirnya dua pesantren besar yakni Pesantren Manbaus Sholihin dan Pesantren Darut Taqwa. Dua pesantren tersebut berada di tengah-tengah desa dan turut ambil bagian di setiap perayaan Rebo Wekasan Melalui santri dan alumninya, ritual Rebo Wekasan terdengar dan tersebar ke pelosok tanah air.

\section{Pergeseran Rebo Wekasan; Dari Ritual Keagamaan ke Motif EKonomi dan Politik}

Dari proses konstruksi Rebo Wekasan yang dilakukan oleh Sunan Giri dan Syekh Jamāl al-Dīn Mālik dari momen eksternalisasi, objektifikasi, dan internalisasi saat ini mengalami pergesaran makna dari makna keagamaan ke makna tradisi, politik, dan ekonomi. Pergeseran makna ini sesungguhnya paling tidak dapat dilihat dari tiga aspek, antara lain aspek latar belakang munculnya Rebo Wekasan dan aspek alasan masyarakat Suci menghadiri Rebo Wekasan dan makna Rebo Wekasan bagi masyarakat Suci.

Pada aspek latar belakang munculnya Rebo Wekasan, tampak bahwa sesungguhnya Rebo Wekasan muncul dari latar belakang keagamaan, yaitu perayaan perayaan ini dipercaya dapat menolak musibah dan merupakan ekspresi rasa syukur kepada Tuhan karena telah memberikan kenikmatan berupa sumber air melimpah. 
Setelah momen keagamaan tersebut, kemudian momen itu bergeser pada momen tradisi, sosial, politik, dan ekonomi. Pada momen tradisi, penyelenggaraan Rebo Wekasan dilatarbelakangi oleh kepentingan bahwa Rebo Wekasan merupakan tradisi masyarakat Desa Suci sejak dulu yang dibentuk oleh Sunan Giri bersama Syekh Jamāl al-Dīn Mālik melalui tindakannya untuk mengajak masyarakat untuk melakukan ritual pada setiap hari Rabu terakhir bulan Safar.

Selain momen tradisi, Rebo Wekasan juga mengalami pergeseran menjadi momen politik sehingga dalam penyelenggaraannya ada campur tangan kepentingan pemerintah. Kepentingan pemerintah, terutama pemerintah desa sesungguhnya dilatarbelakangi oleh kepentingan untuk melestarikan warisan tradisi yang dimiliki oleh masyarakat Suci. Sebab Rebo Wekasan merupakan identitas dan bagian dari kesejarahan Desa Suci. Oleh karena Rebo Wekasan merupakan kepentingan masyarakat Suci secara umum dan bukan kepentingan individu di mana dalam mengelola Rebo Wekasan paling tidak terdapat tiga aspek yang harus dikelola oleh pemerintah desa meliputi;

Pertama, pemerintah desa sebagai panitia penyelenggara yang bertugas mengatur, mengelola, dan menjalankan perayaan Rebo Wekasan. Kedua, pemerintah desa mengelola dan mengatur keamanan Desa Suci secara keseluruhan saat berlangsung Rebo Wekasan agar tidak terjadi hal-hal yang tidak diinginkan. Ketiga, pemerintah desa sebagai pemimpin politik Desa Suci mengatur administrasi pedagang sekaligus membagi stand perdagangannya saat Rebo Wekasan berlangsung.

Adapun pergeseran makna Rebo Wekasan juga memiliki latar belakang ekonomi, antara lain: Pertama, bagi para pendatang maupun masyarakat Suci, diselenggarakannya Rebo Wekasan memiliki latar belakang sebagai sebab terhadap lahirnya kehidupan perdagangan bagi mereka dalam rangka mencari keuntungan ekonomi guna dapat memenuhi segala kebutuhan dan keinginannya yang awalnya bentuk dagangannya sederhana yang berupa makanan dan minuman saja dan sekarang ini bentuk dagangannya lebih bervariasi yang berupa makanan, minuman, pakaian, mainan, jasa hiburan dan lain sebagainya.

Kedua, bagi lembaga-lembaga kemasyarakatan diselenggarakannya Rebo Wekasan memiliki latar belakang sebagai penyebab peningkatan pendapatan lembaga-lembaga kemasyarakatan Desa Suci yang bersumber dari usaha parkir untuk pengunjung, sewa tempat stand, dan juga melalui infak dan sedekah yang diberikan oleh pengunjung Rebo Wekasan. Ketiga, bagi masyarakat Suci, penyelenggaraan Rebo Wekasan dilatarbelakangi oleh pendapatan keuntungan saat pelaksanaan Rebo Wekasan dimana keuntungan tersebut berupa pening- 
katan pendapatan melalui persewaan listrik dan air untuk stand pedagang dan masyarakat suci juga mendapat keuntungan berupa perolehan banyak gula yang mereka terima dari para pengunjung yang bertamu di rumah mereka.

Pada aspek alasan masyarakat Suci menghadiri Rebo Wekasan juga mengalami pergeseran dari momen keagamaan ke momen tradisi, politik dan ekonomi. Pada awalnya masyarakat menghadiri Rebo Wekasan untuk tujuan keagamaan di mana mereka mengikuti rangkaian kegiatan Rebo Wekasan unt uk mengekspresikan rasa syukur kepada Allah, menyucikan diri dan dijauhkan dari marabahaya serta mengikuti doa bersama dan tabarrukan. Dari momen keagamaan ini kemudian Rebo Wekasan mengalami pergeseran ke momen tradisi dimana masyarakat suci menghadiri Rebo Wekasan bertujuan sekadar untuk melestarikan tradisi ulama terdahulu. Tidak hanya bergeser pada momen tradisi saja, tetapi juga bergeser pada momen politik.

Apabila perayaan Rebo Wekasan bersamaa dengan hajatan politik, misalnya pilpres, pileg, pilkada atau pilkades, maka akan banyak tokoh politik yang datang pada saat perayaan. Mereka bukan sekadar hadir pada acara istigasah, tetapi juga memberikan sumbangan terhadap kegiatan masyarakat. Sisi lain juga akan banyak ditemukan spanduk, baliho, umbul-umbul dan segala atribut yang berisikan ajakan untuk mendukung atau memilih partainya dan dirinya.

Oleh karenanya, berdasarkan kedua hal tersebutlah penyelenggaraan dan pelaksanaan Rebo Wekasan dikelola dan diatur oleh pemerintah desa yang merupakan lembaga politik untuk menciptakan kesejahteraan dan kebaikan bersama melalui penciptaan sebuah sistem yang adil. Selain itu, Rebo Wekasan juga bergeser menuju momen ekonomi di mana banyak pengunjung yang datang yang bertujuan untuk memperoleh keuntungan yang sebesar-besarnya melalui tindakan perdagangan yang mereka lakukan dengan berbagai pola, ada yang berdagang makanan, minuman, pakaian, mainan, jasa hiburan dan lain sebagainya.

Masyarakat yang berjualan berjejer di sepanjang jalan Desa Suci hingga desa Pongangan, atau kurang lebih $2 \mathrm{~km}$. Pengelolaan stand diatur oleh desa. Kegiatan tersebut berlangsung selama dua minggu, satu menjelang dan satu minggu lagi sesudah perayaan. Pada saat acara puncak, jumlah pengunjung semakin padat. Namun demikian mereka datang ke Suci bukan untuk mengikuti acara ritual, melainkan untuk belanja dan jalan-jalan. Meskipun ritual acara sedang berlangsung, masyarakat tidak peduli. 


\section{E. Simpulan}

Perayaan Rebo Wekasan terbentuk dari konstruksi sosial yang diciptakan oleh masyarakat, yakni meliputi proses eksternalisasi, objektifikasi dan internalisasi. Dalam proses eksternalisasi, bahwa sejarah Rebo Wekasan diawali dengan penyiaran agama Islam oleh Sunan Giri bersama Syekh Jamāl al-Dīn Mālik dengan segala dinamika dan pernak perniknya. Dalam proses objektifikasi, para ulama dan masyarakat berusaha melembagakan proses tersebut dalam tradisi perayaan dan ritual—sebagai salah satu wujud syukur atas ditemukannya sumber air di desa tersebut. Sementara dalam proses internalisasi masyarakat masuk pada ruang lain, di bawah kesadaran mereka, bahwa seolah tradisi tersebut menjadi niscaya dan kebutuhan batin yang harus dipertahankan. Internalisasi berlangsung cukup lama dan berlanjut hingga sekarang. Pada momen Rebo Wekasan masyarakat, pesantren, pemerintah desa dan pemerintah daerah terlibat secara aktif dalam melaksanakan, mempraktikkan dan mengembangkan tradisi. Di bebarapa peristiwa terakhir, Rebo Wekasan berkembang menjadi sebuah industri-di mana motif ekonomi dan politik mengambil peran di dalamnya. Awalnya ritual Rebo Wekasan dilakukan dengan cara sederhana, seperti salat sunah, mandi dan membaca sholawat Nabi. Namun bersamaan dengan perjalanan waktu, ritual ini dilakukan secara besar-besaran dengan melibatkan beberapa pemangku kepentingan di tingkat lokal desa hingga level Kabupaten. Bersamaan dengan itu pula, jumlah pengunjung dan jamaah yang merayakan juga mengalami peningkatan. Pergeseran momen ritual ke momen politik dan ekonomi tidak terhindarkan.

\section{Daftar Pustaka}

Berger, Peter \& Luckmann. 1990. Tafsir Sosial atas Kenyataan: Risalah tentang Sosiologi Pengetahuan. Terj: Hasan Basari. Jakarta: LP3ES.

Berger, Peter. 1991. Langit Suci: Agama sebagai Realitas Sosial. Jakarta: LP3ES.

Bungin, Burhan. 2006. Sosiologi Komunikasi; Teori, Paradigma dan Diskursus Teknologi Komunikasi di Masyarakat. Jakarta: Kencana.

Geertz, Clifford. 1981. Abangan, Santri dan Priyayi dalam Masyarakat Jawa. Jakarta: Pustaka Jaya.

Katsir, Ibnu. 1999. Ringkasan Tafsir Ibnu Katsir, Juz. 13. Jakarta: Gema Insani Press. 
Ricklefs, M.C. 2013. Mengislamkan Jawa; Sejarah Islamisasi di Jawa dan Penantangnya dari 1930 Sampai Sekarang. Terj. Dono Sunardi dan Satrio Wahono. Jakarta: Serambi.

Miftach. 2008. "Sejarah Rebo Wekasan Desa Suci Manyar Gresik" dalam Dokumen Desa: Tidak diterbitkan.

Mulder, Niels. 1999. Agama, Hidup Sehari-Hari dan Perubahan Budaya. Jakarta: Gramedia Pustaka Utama.

Mustopo, Habib. 2001. Kebudayaan Islam di Jawa Timur. Yogyakarta: Jendela. Ritzer, G. 1992. Sosiologi Ilmu Pengetahuan Berparadigma Ganda. Jakarta: Rajawali Press.

Sobur, Alex. 1998, Analisis Teks Media, Suatu Pengantar untuk Analisis Wacana, Analisis Semiotik dan Analis Framing. Bandung: Remaja Rosdakarya

Tim Penyusun Sejarah Hari Jadi Kota Gresik, 1991. Kota Gresik: Perspektif Sejarah dan Hari Jadi. Gresik: Pemkab Gresik.

Woodward, Mark R. 2006. Islam Jawa Kesalehan Normatif Versus Kebatinan. Terj. Hairus Salim HS. Yogyakarta: LKiS.

Wirawan, 2012. Teori-Teori Sosial dalam Tiga Paradigma: Fakta Sosial, Definisi Sosial dan Perilaku Sosial. Jakarta: Kencana.

Weber, M. 1978. Economy and Society: An Outline Of Interpretative Sociology. Berkeley: University of California Press.

Wawancara dengan Fahmi (Tokoh Masyarakat), 23 dan 28 September 2014.

Wawancara dengan Syahid (Ulama'/tokoh masyarakat), 24 dan 27 September 2014.

Wawancara dengan Arifin (Ulama'/tokoh masyarakat), 24 Agustus, 14 November 2015 dan 15 Agustus 2015.

Wawancara dengan Kepala Desa, 23 Agustus 2015 dan 12 Juli 2015. 